A POTÊNCIA I IMAGENS EM UMA MISCE AMAZÔNICA: SOCIABILID ESTILO DE VIDA NOS PÁS JUNINOS DE BELÉM 


\section{A POTÊNCIA DAS}

IMAGENS EM UMA MISCELÂNEA AMAZÔNICA: SOCIABILIDADE E ESTILO DE VIDA NOS PÁSSAROS JUNINOS DE BELÉM-PARÁ

ELIANE SUELEN OLIVEIRA DA SILVA UNIVERSIDADE FEDERAL DO PARÁ, BRASIL

FLÁVIO LEONEL A B REU DA S I LVEIRA UNIVERSIDAdE FEDERAL do PARÁ, BRASIL

HELIO FIGUEIREDO DA SERRA NETTO 


\section{Resumo}

\section{A POTÊNCIA DAS IMAGENS EM UMA MISCELÂNEA AMA- ZÔNICA: SOCIABILIDADE E ESTILO DE VIDA NOS PÁSSAROS JUNINOS DE BELÉM (PA)}

Os Pássaros Juninos ou Pássaros Melodrama-Fantasia representam um tipo de teatro musicado próprio do Pará. Eles possuem como referenciais elementos de diversos gêneros teatrais e de manifestações regionais, trazendo à tona fontes das culturas negra, branca e indígena, que desde a colonização da região se miscigenaram, resultando naquilo que hoje entendemos por "cultura amazônica". Este trabalho pretende discutir o caráter mestiço que engendrou as circunstâncias do surgimento dos Pássaros Juninos e, por conseguinte, explicitar que tal manifestação evoca distintas imagens que convergem na construção de narrativas amazônicas fantásticas expressas sob a forma de sociabilidades singulares ao contexto paraense.

Palavras-chave: imagens, mestiçagem, Pássaro Junino.

\section{Abstract \\ THE POWER OF IMAGES IN AN AMAZON MISCELLANY: SO- CIABILITY AND LIFESTYLE IN THE PÁSSAROS JUNINOS OF BELÉM (PA)}

The Pássaros Juninos (Birds of june) or Bird melodrama-fantasy represent a type of musical theatre that is typical of Pará. They have elements of various theatre genres and regional manifestations as reference points, and bring to the surface sources from the African, Caucasian and indigenous cultures, which since the onset of colonisation in the region have miscigenated, resulting in what we now understand as being "Amazon culture". This paper intends to discuss the mestizo character that has engendered the circumstances of the appearance of the Pássaros Juninos, and, consequently, explain that such a manifestation evokes distinct images that converge in constructing fantastic Amazon narratives expressed in the form of sociabilities that are unique to the Pará context.

Keywords: images, mestizo process, Pássaro Junino. 


\section{Résumé}

\section{LA PUISSANCE DES IMAGES DANS DES MISCELLANÉES AMA- ZONIENNE: SOCIABILITÉ ET STYLE DE VIE DANS LES PÁSSA- ROS JUNINOS DE BELÉM (PA)}

Les Pássaros Juninos (les oiseaux de juin) ou Oiseaux mélodramefantaisie représentent un type de théâtre accompagné de musique propre de l'Etat du Pará. Ils ont comme références des éléments de divers genres de théâtre et de manifestations régionales et font apparaitre des sources des cultures des noirs, des blancs et des indiens, qui ont métissé depuis la colonisation de la région, ce qui a donné origine à ce qu'on appelle actuellement la «culture amazonienne». Ce travail a pour but de discuter le caractère métis qui a engendré les circonstances de la naissance des Pássaros Juninos et, par conséquent, d'expliciter qu'une telle manifestation évoque des images distinctes qui aboutissent à la construction de narratives amazoniennes fantastiques exprimées sous la forme de sociabilités singulières dans le contexte de l'Etat du Pará.

Mots-clés : Images, métissage, Pássaro Junino. 


\section{INTRODUÇÃO}

O intuito principal deste artigo é o de realizarmos uma reflexão acerca da simbólica das imagens presentes nos chamados Pássaros Juninos ou Joaninos - uma manifestação teatral peculiar à região amazônica, cuja presença em alguns bairros da cidade de Belém pode ser apreciada durante os folguedos juninos. Ao tomarmos a brincadeira como uma expressão de sociabilidade formal (Simmel 1983), partimos do pressuposto de que a representação teatral revela aspectos interessantes das maneiras de viver e do estilo de vida próprios aos moradores das áreas periféricas belenenses, entre elas algumas conhecidas localmente como "baixadas". O theatrum mundi paraense é alegorizado a partir de uma sensibilidade coletiva que emerge com força entre os brincantes ${ }^{2}$ dos Pássaros Melodrama-Fantasia, traduzindo mazelas do cotidiano vividas pela população mais pobre que parodia as relações de poder e assimetrias sociais ${ }^{3}$, tornando-as risíveis sem deixar de revelar os dilemas da vida social (Charone 2009).

Para tanto, enfocaremos as formas sociais que constituem tal manifestação popular a fim de percebermos como elas foram pensadas historicamente e, assim, visualizarmos quais as características mais ressaltadas por aqueles que outrora se dedicaram ao seu estudo, tentando aproximá-los de estudos mais recentes em consonância com as nossas observações de campo no ano corrente.

Como o artigo trata da apreciação de algumas imagens - visuais e perfor- máticas - que compõem a brincadeira, pontuaremos as perspectivas teóricas que achamos ser mais convenientes ao propósito das reflexões que intentamos acerca de tal manifestação, uma vez que as imagens que iremos referir estão presentes em fotografias e gravuras que auxiliarão no processo interpretativo do fenômeno pesquisado. Sendo assim, iremos dispô-las ao longo do texto de forma que se integrem à narrativa textual. E, é neste segundo momento, que abordaremos melhor como iremos desenvolver as veredas dessa análise, refletindo sobre o estatuto da imagem, ressaltando-lhe a importância hermenêutica que sinaliza para a sua potência narrativa frente à experiência lúdica e criativa dos brincantes. Por fim, buscaremos encontrar algumas homologias relativas às imagens dos Pássaros Juninos em relação a outras experiências de sociabilidade e de religiosidade, capazes de revelar estilos de vida relacionados às formas sensíveis da vida social (Sansot 1979) presentes no norte do país. Portanto, ao refletirmos sobre o que a imagética da brincadeira nos aponta e a que outras imagens podemos remetê-la - pensando a constituição e a convergência de imagens na narrativa do melodrama-fantasia que compõe os Pássaros - buscaremos explicitar o caráter mestiço das imagens elaboradas pelos brincantes, a partir de apropriações/re-significações de um imaginário fantástico presente no contexto amazônico com marcante diversidade de elementos étnicos em sua composição. 
PÁSSAROS: UM (SOBRE)VOO HISTÓRICO PELAS PAISAGENS BELENENSES DE OUTRORA

A colonização do território brasileiro desde o seu início esteve permeada pela imposição de fronteiras de âmbito religioso, as quais os colonizadores portugueses acionaram como forma de controle das populações nativas, seja quanto aos seus corpos (lembrando as reflexões de Foucault 2007), como da colonização de seus imaginários (mediante a uma "guerra de imagens", como sugere Gruzinski 1991, 1992). O teatro paraense enquanto manifestação artística também teve sua origem relacionada à religião cristã difundida por tais colonizadores. Segundo Loureiro (1995), nesse período o objetivo de instalar o teatro era o de catequizar os nativos - visando à conquista espiritual (Montoya 1997) - através de peças que apresentavam um mundo de caráter maniqueísta constituído pelo antagonismo existente entre as forças divinas (Tupã-Deus) e as demoníacas (Anhangá-Demônio).

Todavia, a partir do século XVIII, ainda no período colonial, nota-se o deslocamento de tal perspectiva, com o surgimento dos teatros paraenses vistos enquanto locais próprios às manifestações consideradas como sendo mais artístico-teatrais do que pedagógicojesuíticas. Entre os espaços de apresentação existentes à época na capital paraense, se tem registros da Casa da Ópera, inaugurada em 1775, bem como do Teatro Chalet, em 1873. Enquanto na primeira ambiência predominaram apresentações de óperas, autos pastoris, dramas musicados e coros de índios, no segundo viram-se baixas comédias ou chanchadas, as quais marcaram o gênero que ficou conhecido como teatro nazareno (Loureiro 1995).

Mais tarde, em 1878 e em plena Belle Époque 4 amazônica, época de intensificação do processo de urbanização belenense propiciado pelo lucrativo comércio da borracha, surge o Theatro Nossa Senhora da Paz, onde predominaram as apresentações de óperas, peças, danças e musicais vindos do exterior para a satisfação da emergente elite paraense. Por sua vez, a Belle Époque paraense - cujo Teatro da Paz enquanto monumento representa o esplendor da época - produziu uma organização do espaço dicotomizante, uma vez que excluiria e ocultaria os grupos detentores de costumes, então, considerados espúrios à cidade civilizada. Neste período "vê-se, portanto, cenas de uma cidade que transita constantemente entre um projeto de modernização e a convivência com costumes construídos como tradicionais" (Cancela 2009: 224), tornando evidente a paisagem urbana enquanto espaço de transitividade.

Enquanto isso as brincadeiras de rua eram praticadas em lugares de ampla circulação de seus moradores, como é o caso do boi-bumbá, sobretudo, por negros e pobres moradores de alguns bairros da cidade. A existência desses grupos no mundo urbano indicava um estilo de vida com forte apelo estético relacionado ao lúdico e às redes de sociabilidade que giravam em torno dos jogos $^{5}$, das danças e das representa- 
ções juninas, revelando um saber-fazer voltado à produção de enredos e cenografias festivas. No entanto, os notórios e acirrados encontros de grupos de boi que concorriam entre si acabaram sendo reprimidos pela polícia sob ordens do poder público, sendo proibidos de se apresentarem nas ruas a partir do ano de 1922.

Tais práticas acabariam sendo confinadas aos chamados "currais" ou "terreiros" existentes em bairros periféricos da cidade. Segundo Moura (1997), esta medida restritiva acarretou mudanças na estrutura do folguedo do boi-bumbá, bem como contribuiu para a expansão de outras manifestações culturais, na medida em que tais expressões se encontravam em um espaço comum resultando em trocas de experiências. Salles (1994), por sua vez, argumenta que da situação de opressão tirou-se proveito para transformar os "currais" em espaços de festividade, onde foram construídos tablados a fim de que os grupos pudessem apresentar o que estavam proibidos de fazer nas ruas de Belém. Nos currais encontravam-se os grupos de bois e outros cordões de bichos ${ }^{6}$, que logo tomaram forma de teatro popular, onde a comédia passa a ter espaço primordial.

Nesse mesmo período ocorre a queda do comércio da borracha, com suas duras conseqüências para a economia paraense, fazendo com que as peças que vinham majoritariamente da Europa para se apresentar no Teatro da Paz ficassem cada vez mais escassas no panorama cultural da cidade. Justo nesse momento de crise que, segundo
Refkalefsky (2001), os sujeitos que outrora colaboravam para a vinda das grandes óperas importadas passaram a contribuir significativamente para o trabalho das manifestações artísticas regionais. Segundo a autora:

"Por um lado, os artistas populares da região, que no auge do período da borracha, se encontravam relegados a um segundo plano, encontraram com a crise, um público e um espaço para se manifestarem. Por outro, os artistas, músicos e escritores desempregados passam a aplicar seus conhecimentos junto ao povo e à elite, alternadamente" (Refkalefsky 2001: 40).

Muito embora esta análise mereça ressalvas por enfatizar a suposição de que tais manifestações ditas "populares" estariam inicialmente desprovidas de "um público e um espaço", ou ainda, que somente conseguiram apreciadores mediante a crise econômica enfrentada pelo teatro europeizado e hegemônico, a análise de Refkalefsky, apoiada em Salles, vislumbra algo que merece destaque a fim de entendermos o que significa o Pássaro Junino no contexto belenense. Trata-se, portanto, de observarmos a questão relativa à assimilação e à re-significação de elementos que parecem, até então, alheios às práticas populares locais. Esses constituintes e valores externos foram aqueles veiculados, sobretudo, pelas manifestações proporcionadas a partir da economia da borracha, como as revistas, os folhetins e as óperas, que ao adentrarem o mundo urbano, onde os grupos de brincantes teriam estabelecido contato com os mesmos, acabaram 
sendo apropriados e (re)interpretados, resultando em um gênero teatral tão significativo ao Pará.

Neste sentido, seguimos a perspectiva de que o popular qualifica "um tipo de relação, um modo de utilizar objetos ou normas que circulam na sociedade, mas que são recebidos, compreendidos e manipulados de diversas maneiras" (Chartier 1995: 6), de modo que a assimilação e a utilização de tais elementos que "circulam" não ocorrem de forma passiva, mas a partir de uma constante releitura e re-significação, que só é possível por conta dos modos de fazer através dos quais se expressam a pluralidade e a criatividade mediante uma arte de intermediação de onde resultam, por certo, efeitos inesperados (Certeau 1994).

$\mathrm{Na}$ complexa interação de conteúdos, símbolos e imagens presentes no contexto que estamos tentando compreender, ou ainda, do efeito dessa arte da intermediação, foram concebidos os Pássaros Juninos ou Pássaros Melodrama-Fantasia. Sendo um gênero teatral característico ao Estado do Pará, sua origem e estrutura remetem a diversas expressões artísticas - religiosas e profanas, mas sempre atravessadas pela força da narrativa mítico-fantástica - como: os cordões de bichos, os bois-bumbás, as pastorinhas ${ }^{7}$, as óperas e os dramas.

Se nos cordões de pássaros a trama é centrada especialmente no roubo de uma ave, seu ferimento e, por conseguinte, sua recuperação (reverberando à própria narrativa do boi-bumbá), nos Pássaros Juninos esta narrativa dilui- se no conjunto de diversas temáticas, como questões amorosas, dramas familiares, preservação da natureza, costumes tradicionais, religiosidade, entre outras $^{8}$. Portanto, a tessitura da intriga narrativa (Ricoeur 1994) contém elementos comuns ao enredo primordial dos Pássaros presentes em Belém, bem como encontram outras temáticas, evocando preceitos ético-estéticos (ethos) e visões de mundo (eidos) caras aos grupos de brincantes.

Como a própria denominação do folguedo indica, é possível perceber que nos Pássaros Melodrama-Fantasia as performances ${ }^{9}$ retratam temas característicos do melodrama, que se identifica essencialmente pela bipolaridade, seja pela alternância entre momentos em que emergem uma série de emoções adversas, como a desolação, a tristeza, a euforia e a alegria, seja pela presença de valores opostos, como o vício e a virtude (Huppes 2001). Todavia, "no universo dramatúrgico dos Pássaros o novo e o velho se misturam, o rico e o pobre, o caçador e o pássaro, o trágico e o cômico" (Refkalefsky 2001: 45). Se as oposições existem, como de fato são marcantes, elas se relacionam e articulam na estrutura essencial do enredo performatizado pelos brincantes no decorrer das festas juninas. A luta do bem contra o mal, pujante nestas narrativas, simboliza de forma profunda tal polaridade conflituosa, o que remonta, também, ao maniqueísmo entre as forças divinas e demoníacas marcantes do teatro jesuítico.

Por sua vez, e não menos importante, o caráter fantástico transparece ao 
retratarem em cena personagens com poderes mágicos e míticos, como seres maravilhosos e figuras lendárias do universo amazônico, capazes de restaurar a ordem corrompida entre os homens e entre estes e a natureza. O caráter fabulatório presente nas narrativas dos Pássaros, por outro lado, evoca imagens do mundo fantástico dos entes encantados e das figuras lendárias do panteão de seres míticos europeus (as fadas, por exemplo).

Moura (1997), que apresenta uma das primeiras tentativas da sistematização de fôlego desta manifestação teatral, conclui que o pássaro junino

"é uma bricolagem das mais disparatadas linguagens: o melodrama, que ali chegou através do repertório encenado pelo teatro de prosa, a partir do século XIX; a comédia de costumes; o romance folhetim e a radionovela; o teatro de revista; a opereta e a dança" (Moura 1997: 20).

O que o aproxima das reflexões de Loureiro, quando o autor constata o seguinte:

"O Pássaro Junino é um exemplo do maravilhoso objetivado que constitui uma das marcas distintivas da arte produzida na Amazônia. Uma alegoria de mestiçagem ou síntese cultural, essa espécie de ópera cabocla se estrutura com elementos da cultura indígena e da cultura européia, revelando, vez por outra, traços da cultura negra” (Loureiro 1995: 324).

Neste sentido, o conceito de bricolagem nos auxilia quanto ao propósito de contemplarmos o Pássaro Junino como verdadeiro mosaico/colagem de conteúdos que representa desde sua indefinível origem, cuja ressignificação sensível e criativa, ao lidar com determinadas circunstâncias práticas e cotidianas, engendrou algo novo e mestiço $^{10}$. A bricolagem lévi-straussiana é justamente este procedimento de construção a partir dos recursos limitados de que se dispõem, podendo alcançar tanto no plano técnico como no intelectual "resultados brilhantes e imprevistos" (Lévi-Strauss 1976: 32).

A questão da bricolagem se faz presente não apenas na estrutura do gênero como no próprio cotidiano dos Pássaros Juninos, o que pôde ser vislumbrado em diversos momentos durante trabalho de campo realizado junto ao Grupo Junino Tucano, envolvendo desde a confecção das roupas - algumas reaproveitadas de outros grupos juninos - até o rearranjo da narrativa a ser apresentada (geralmente escrita há décadas), que é alterada por Iracema, a guardiã do grupo ${ }^{11}$, devido à limitação de brincantes ou por entender que o término original da brincadeira narrada "não está certo". Portanto, neste aspecto a bricolagem fala não apenas com as coisas, mas também "por meio das coisas: contando, pelas escolhas que faz entre possibilidades limitadas, o caráter e a vida de seu autor. Sem jamais completar seu projeto, o bricoleur põe-lhe sempre algo de si mesmo" (Lévi-Strauss 1976: 42).

Portanto, os Pássaros Juninos devem ser contemplados enquanto gênero mestiço e híbrido desde suas origens, 
cuja característica se reflete em seu resultado final, isto é, no palco, ao colocarem justapostos os gêneros melodramáticos, as comédias e as operetas, intercaladas por cantos e danças, bem como personagens como matutos cearenses e paraenses, nobres, "índios brancos", "brancos mestiços", e valores como a fé no poder divino cristão e na feitiçaria, o amor e o ódio, a morte e a ressurreição.
"Até certo ponto é possível perceber como tudo isto se foi aglutinando, justapondo-se, harmonizandose. Pode-se pensar em paralelismos, convergências e semelhanças com o boi bumbá [...]. Outro parentesco se percebe com as danças imitativas de aves e bichos, observadas por alguns viajantes estrangeiros e percorreram a região amazônica no século XIX [...]. Mais algumas influências se fazem

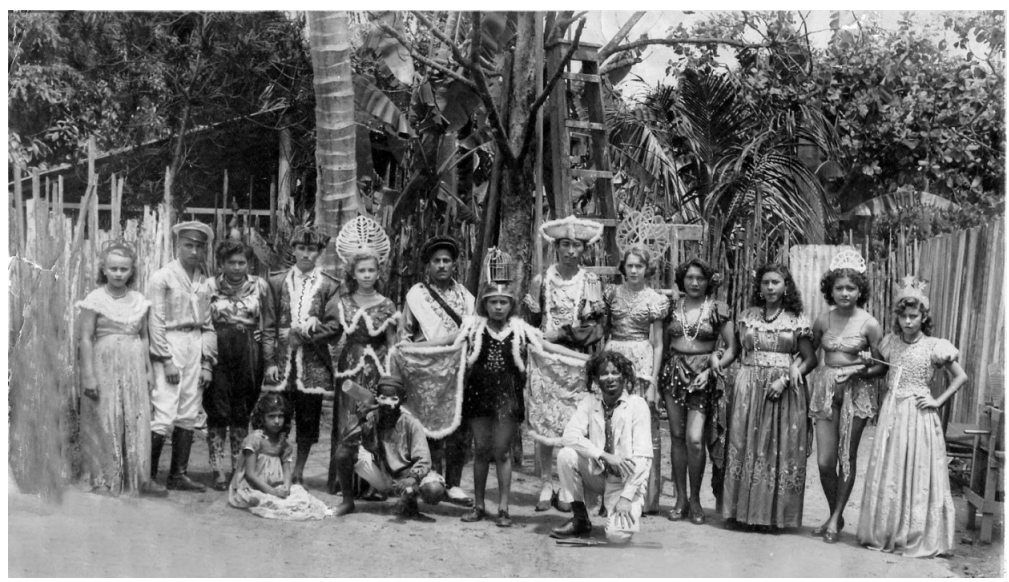

Figura 1 - Fotografia do Pássaro Rouxinol. Autoria e data desconhecidas. Acervo pessoal de Wanderley Rodrigues.

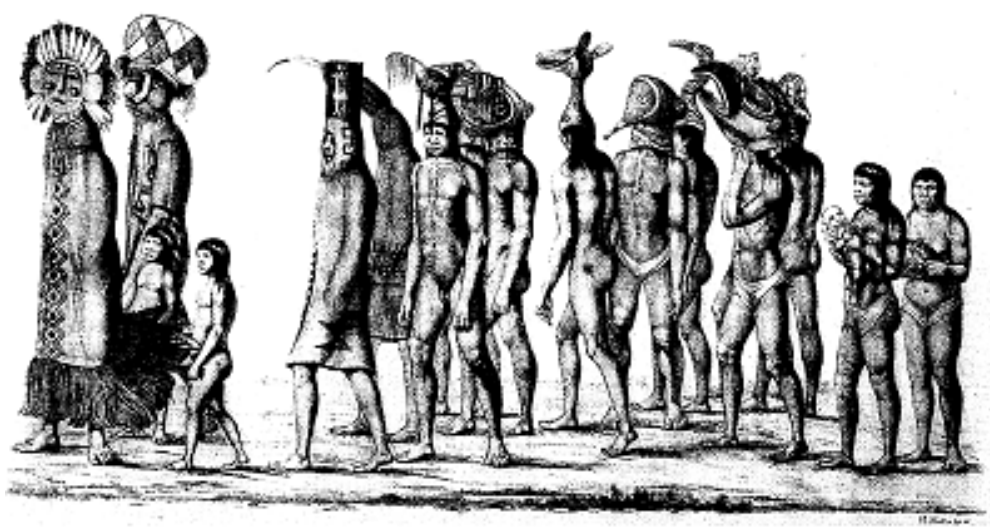

Figura 2 - Gravura dos índios Ticuna. Autoria: Philipp Schmid. Reproduzida da obra de Moura (1997). 


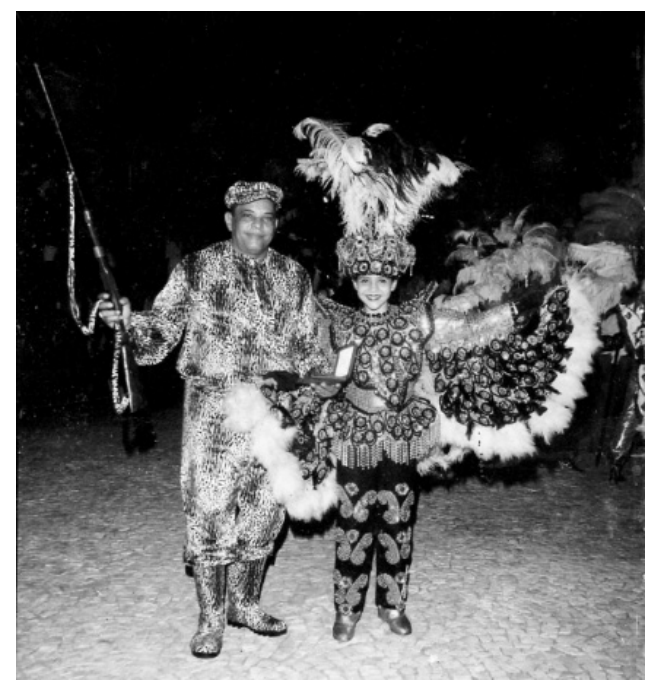

Figura 3 - Fotografia de porta-pássaro e caçador do Pássaro Rouxinol. Autoria e data desconhecidas. Acervo pessoal de Wanderley Rodrigues.

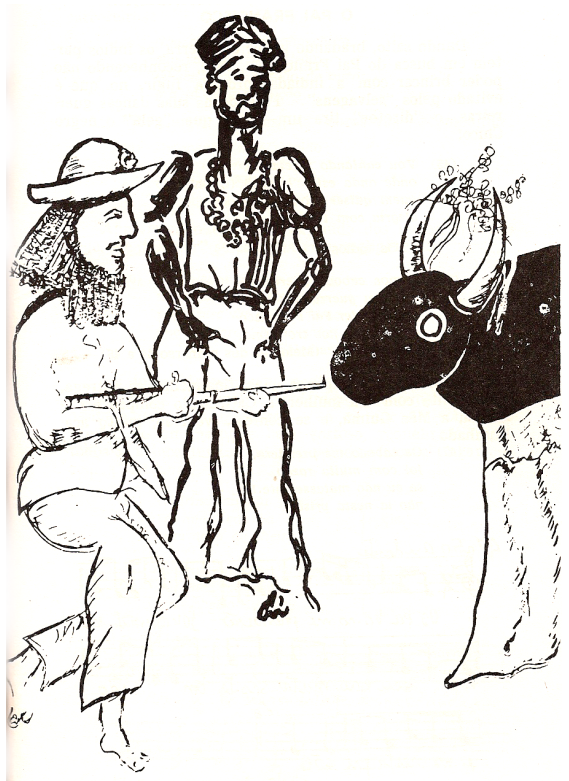

Figura 4 - Gravura de Boi-bumbá. Reproduzida da obra de Menezes (1972).

notar: a das pastorinhas e de uma manifestação de popular, o teatro dito nazareno [...], cujo repertório se apoiava no melodrama e na baixa comédia" (Moura 1997: 20).

\section{O VOO SUTIL DAS IMAGENS}

Considerando os Pássaros Juninos enquanto manifestações mestiças, temos que as suas narrativas, por conseguinte, evocam distintas imagens que convergem e imbricam-se, remontando a passados históricos e a memórias coletivas ligadas ao cotidiano, bem como de teor fantástico. A imagem, assim, deve ser contemplada por um olhar sensível, buscando mergulhar na densidade das experiências simbólicas que carrega, onde o Pássaro, por certo, revela nuances da vida vivida e do saber-fazer dos grupos sociais que o experienciam no contexto belenense.

Aqui não nos interessa analisar as imagens de um ponto de vista puramente racional, pois o nosso interesse caminha entre as brumas que escapam a esse tipo de análise. Para isso é preciso certo "irracionalismo" para duvidar dessas construções sistemati- 
camente sustentadas e binariamente construídas e, desta maneira, adentrar no mundo poético das imagens. Mundo este que predomina o feminino, o irracional e o imaginal, elementos fundamentais para uma compreensão mais dinâmica e menos racionalista, já que para conhecer também é preciso imaginar (Bachelard 2006).

O devaneio se torna uma questão chave nesta perspectiva, pois busca esse outro viés que as imagens nos suscitam, que fogem ao excessivamente masculino e ao racional. Não buscamos, de forma alguma, evocar as imagens como meras ilustrações de conceitos, ou como uma forma de atestar a "verdade", o que nos interessa é perceber como elas nos ajudam a imaginar o Outro - ou ainda, imaginar a imaginação do Outro - e assim a conhecê-lo um pouco melhor. Partindo do pressuposto que as imagens atuam no âmbito da comunicação e que os indivíduos e o social se expressam por elas, é importante perceber o que essas imagens realçam, ou de que maneira o corpo e os gestos individuais nos remetem ao corpo coletivo e às expressões culturais em sua dinâmica reveladora do sensível, presente no divino social em seus espaços ritualísticos de celebração (Maffesoli 1994).

No caso dos Pássaros Juninos, onde a mestiçagem é uma das suas características mais marcantes, nota-se que a vestimenta dos personagens, a corporificação e o gestual aparecem como os elementos mais importantes de marcação dessa característica mestiça, pois neles o imaginário, o fantástico e o mitológico são invocados como uma forma expressiva e performática de comunicação entre o corpo individual e o corpo social, e é nessa corporificação sutil que "une" subjetividades em torno de um "estar-junto em comunhão", que o corpus social expressa sua lógica (Maffesoli 1987).

Já que o corpo engendra comunicação, "é, portanto, o horizonte da comunicação que serve de pano de fundo à exacerbação da aparência" (Maffesoli 1996: 104), e é preciso reter o que ela nos faz ver. Ir ao fundo das aparências é adentrar neste imaginário, de tal modo que percebamos suas nuances, suas cores, e principalmente o que elas nos fazem ver, pois “a 'forma' é a mediação entre o eu e o mundo natural e social". Nesta perspectiva, evocamos o mundo imaginal a partir da leitura que Maffesoli faz dele, enquanto um todo feito por imagens, imaginações e símbolos, que constrói a vida social e ordena as imagens e experiências mundanas através da inteligência figurativa, tornando possíveis as imagens sociais, cujo reconhecimento e compreensão são compartilhados.

Ao homem, a quem foi inculcado durante séculos uma pedagogia cientificista e autoritária, cabe desamarrar-se "das tentações do imobilismo e passividade propostas pelo século" (Durand 1995: 51), a fim de viver uma experiência simbólica profunda através das imagens que emergem nos mais diversos momentos de sua existência. Este apelo, contudo, não se trata de reclamar um ato de contemplação passiva e vazia, mas experienciar as imagens com a totalidade das faculdades de uma 
inteligência ativa (Durand 1995: 51).

Desamarrar-se do imobilismo e da passividade, como nos propõe Durand, é primordial para qualquer análise acadêmica e, para se aproximar minimamente da realidade dos Pássaros Juninos, esta condição é não apenas primordial como prioritária. Levamos em consideração que essas manifestações populares não sofreram, pelo menos significativamente, influência direta da pedagogia cientificista, de um racionalismo exacerbado, ou mesmo, de um "desencantamento do mundo". Pelo contrário, elas se apresentam como a oposição desses conceitos, já que nelas se torna evidente o trunfo das imagens, o mundo encantado em vários sentidos, e mais, elementos do irracionalismo que somente as manifestações populares podem proporcionar à plateia ávida pela dança dos símbolos e das imagens. Nesse sentido, uma análise cientificista para compreender o fenômeno em questão se torna incompatível, pois se distancia a tal ponto do cotidiano dos brincantes de maneira a perder-se em "teorismos" e tornar-se uma análise superficial, porque empobrecedora do voo e da convergência das imagens presentes na ludicidade criativa que os Pássaros ofertam.

O reconhecimento e a leitura das imagens, todavia, devem ser respeitados enquanto movimentos sociais e individuais, uma vez que a recepção da imagem não é independente da relação que a mesma mantém com a experiência ou repertório do receptor (Ribeiro 2004). Sua significação também é, portanto, exterior e anterior, por situar-se na experiência coletiva, mas reunida no sujeito que a experiência como plateia, compartilhando as visões de mundo veiculadas na brincadeira. As narrativas por imagens são, portanto, ecos de outras narrativas, residindo entre diferentes percepções e intenções. Para Manguel (2001: 32), não à toa, “a arte acontece", por ser sempre um convite a uma leitura diferente através de uma gramática criada a partir da imagem constituída, mas cujo código se dá apenas através dos nossos conhecimentos anteriores, pois "só podemos ver as coisas para as quais já possuímos imagens identificáveis" (Manguel 2001: 32).

Devemos aqui frisar que nossa intenção não é a de fornecer uma leitura única às imagens que serão abordadas e tão pouco de constituí-las como "provas" do que iremos apontar; o que pretendemos é mostrar como elas nos ajudam a compreender essas manifestações culturais, percebidas enquanto expressões de formas sensíveis de composição de estilos e maneiras de viver a exuberância das imagens no contexto amazônico. Sendo assim, as imagens a que nos referimos aqui-que constelam em torno do Pássaro como manifestação simbólico-cultural - narram experiências individuais, memórias coletivas, passados históricos, fantasias e mitos em um processo dinâmico.

O seu estatuto não é o de mera ilustração subjugada ao texto, posição a que foi relegada e que a Antropologia da Imagem hoje trata de desconstruir, mas enquanto potência que conta outras histórias além-texto, densas, viajando nos meandros das experiên- 
cias de quem as produz, tentando circunscrevê-las no tempo e no espaço; e do receptor que também colabora para sua construção num movimento inverso, ao explorá-las com o olhar a fim de abrir-se para um universo fértil de leituras possíveis. A imagem, assim, nunca está terminada porque é um processo que resulta de uma evocação e de uma hermenêutica engendradas por quem lança o olhar a um determinado fenômeno. Uma imagem sempre suscita outras, bem como hermenêuticas possíveis.

Se esta imagem, por fim, carrega um mundo próprio e autônomo, permitindo que o leitor nela se refugie e se reinvente, ela deve ser relacionada à ficção. Ainda assim, mesmo a imagem enquanto documento não foge dos meios de ficcionalização, pois ela é algo construído, seja através dos cortes iniciais que a determinam espaçotemporalmente, seja pela imaginação criadora que a contempla, expande e relaciona com outras imagens. "O ato poético da descoberta, o estabelecimento de relações entre elementos que então estavam separados é, com efeito, o empreendimento ficcional que nós reclamamos uso e reconhecimento" (Piault 2001: 169).

Sendo assim, não estamos empenhados em construir "a" narrativa no sentido unívoco da palavra, pois se a nossa "ficcionalização" tem "pretensão de verdade", não se constitui, entretanto, como a verdade em si. Sabendo de nossas limitações, e de quão "falsa" pode ser uma "verdade" "academicamente" respaldada ${ }^{12}$, temos em mente o fato de que nossas narrativas devem se constituir como um meio termo, que partindo da ideia de "ficção" enquanto construção, pretende atingir a noção de "verdade" enquanto uma das interpretações possíveis do real. Para tal, pretendemos que essas imagens nos impulsionem ao exercício de interpretar o que fica de "não-dito" quando elas tentam nos dizer algo, para aludir à Gadamer (2002), e é nesse exercício interpretativo que buscamos ir além da lógica reflexionante, adentrando nos meandros do imaginativo e da poesia.

A partir de tais considerações, convidamos o leitor a, conosco, reler e reconstruir imagens que já são em primeira instância leitura e construção do que encontramos e, imaginativamente, percebemos por Pássaro Junino. Em seu caráter mestiço e através de seu mosaico - talvez caleidoscópio - imagético, os Pássaros evocaram em nós diferentes imagens que aqui buscaremos relacionar, na tentativa de trazer à tona a sua poética.

\section{O QUE NOS DIZEM AS IMA- GENS NOS PÁSSAROS JUNINOS}

As imagens que iremos considerar são fotografias ou reproduções de fotografias presentes em livros, revistas e outras fontes consultadas. Algumas destas fotografias foram feitas especificamente para a realização deste trabalho, com o intuito de construir uma narrativa etnográfica a partir do uso de imagens. Estas foram produzidas durante uma apresentação do Pássaro Tucano, no Teatro do Museu Emilio Goeldi na 
noite do dia 20 de junho de 2009, em Belém do Pará ${ }^{13}$. Naquele momento, o Pássaro Tucano encenou a peça intitulada "A vingança de uma Feiticeira", todavia, buscaremos não deter nossas reflexões nesta peça somente e diretamente, já que pretendemos falar dos Pássaros Juninos de maneira mais geral. A especificidade dessa manifestação cultural será tratada a partir de seus pontos em comum, vislumbrando suas semelhanças com outras narrativas já conhecidas, de forma a perceber como elas se constituem como um evento artístico que mobiliza as pessoas.

Quais seriam esses pontos em comum? De maneira geral, os Pássaros Juninos têm como uma de suas características o "real" misturado com o fantástico, tratando-se de cenas que retratam o cotidiano, que, no entanto, estão permeadas - as cenas - por seres fantásticos e encantados. Sua estrutura se dá basicamente em torno de alguns grupos de personagens, que pertencem geralmente às seguintes categorias, assim denominadas pelos brincantes: nobreza, composta por fidalgos, príncipes, marqueses, imperadores e suas respectivas figuras femininas, cujo vestuário imponente e gestual cerimonioso reflete seu status economicamente "superior" aos demais; matutagem, que são caboclos paraenses e cearenses detentores de estilos de vida caracterizados por maneiras de falar e agir, cujas visões de mundo veiculam saberes e fazeres que os singularizariam; maloca, que se trata da organização aldeã de uma tribo indígena, composta por índios ordinários, guerreiros e um chefe, temidos pelos demais personagens; e, por fim, seres encantados, entre eles fadas e princesas da floresta, que aparecem em visões para alguns personagens e são capazes de antever acontecimentos e restaurar a ordem.

Como citado anteriormente, nos Pássaros Juninos o enredo remete sempre à vida de um pássaro, cuja denominação indica ser ele o patrono do grupo junino. Em torno desta imagem convergem as demais que compõem a intriga e se entrelaçam outras narrativas que ocorrem em diferentes "grupos" (a nobreza, a maloca e a matutagem, conforme explicitado) e que representam, de maneira emblemática, um rico acervo de imagens que constitui o imaginário de caráter popular presente no contexto amazônico paraense, bem como nos instigam a refletir sobre a relevância da imagem e a sua narrativa poética, considerando-se a perspectiva ético-estética dos grupos brincantes.

O pássaro patrono é sempre representado na peça por uma criança que traz sobre a cabeça uma alegoria com a figura da ave que dá nome ao grupo junino. A criança é denominada de porta-pássaro, tendo por responsabilidade representar o bicho, imitando seus movimentos, que ganham vida graças também ao seu figurino, o qual normalmente é um dos destaques da apresentação. Geralmente a criança porta-pássaro é uma menina ${ }^{14}$, que simboliza pureza e inocência frente à humanidade repleta de ambição e de malícia. Certa vez, o "ensaiador" do Pássaro Junino TemTem afirmou que nada impede de ser um menino o porta-pássaro, mas, sa- 
lientou que "o menino não apresenta inocência. Menino é mais sacana. A cara do menino é mais teimosa, né? A da menina não. Você vê a inocência dela, o sorriso [...]. Ela ainda vive com o imaginário na vida dela [...]. o mundo... o mundo é um mar de rosas pra ela".

A fala do "ensaiador" indica a existência de uma dimensão sensível presente nas formas engendradas pelo pássaro que remete à anima, o princípio feminino como referência direta ao imaginário e à ausência de máculas, opondo o animus, o princípio masculino, visto como expressão do profano, como referência ao secular e ao racional ${ }^{15}$.

$\mathrm{Na}$ peça intitulada "A vingança de uma feiticeira”, encenada pelo Pássaro Tucano, o pássaro é oferecido pela fada a uma princesa que foi raptada, simbolizando o presente de um ser mágico àqueles humanos de bom coração. Neste sentido, o pássaro representa a paz de espírito e a própria felicidade.

Noutro momento, o "passarinhador", espécie de amigo e assistente que busca junto com o caçador conseguir capturar o pássaro, menciona que "quem o conseguir será muito feliz e afortunado". O pássaro representa, agora, além de felicidade, belas virtudes e riquezas que o homem deseja possuir, sendo por isso alvo de cupidez e desejo. Este embate apresenta-se em seu ápice no momento da caçada, ação que sempre ocorre na estrutura do Pássaro Junino, muito embora de forma difusa entre outras narrativas, quando o caçador tenta aprisionar o pássaro, ferindo ou matando-o. A guardiã do Tucano em diversos momentos afir- mou preferir usar o termo "alvejar" ao invés de "atirar" ou "matar" o pássaro, por entender que ele não deve morrer em momento algum da trama.

De qualquer forma, morrendo, sendo somente ferido ou alvejado, a existência do pássaro é assegurada pelos poderes de um ser mágico, através do qual é salvo, curado ou ressuscitado.

Assim, o pássaro carrega o espetacular imortal, a persistência e a perseverança da bondade acima da maldade. Ele é o elemento da natureza em sua concepção básica, enquanto integrante da fauna amazônica, mas seu significado extravasa seu ser material ao dialogar com a vida e a morte, torna-se um fabuloso ente mítico. Assim, o pássaro é um "elo do sobrenatural e o natural. É um mensageiro da bybris posto que é mortal e divino. Sendo mortal morre para renascer mais tarde devido sua condição sobrenatural própria dos imortais ${ }^{16}$. É um intermediário entre o céu e a terra" (Loureiro 1995: 327).

Paes Loureiro aproxima-se da perspectiva de Gilbert Durand, para quem o pássaro é o símbolo diairético que aponta a dialética da ascensão versus a queda e, sendo uma imagem de potência cujas asas têm por fantasia voar, aparece como elemento celeste e de elevação. Sendo ascensão, “o arquétipo profundo das fantasias do vôo não é o pássaro animal, mas o anjo, e que toda elevação é isomorfa de uma purificação porque é essencialmente angélica" (Durand 1995: 94). Vislumbrando uma dimensão cíclica, retornamos assim à imagem da menina porta-pássaro, que simboliza em plenitude a inocên- 
cia e o angelical, assim como o voo e a ascensão do bem sobre a maldade.

A intervenção de seres mágicos na trama se dá normalmente no sentido de preservar ou restaurar a ordem que porventura foi transtornada.
São as figuras angelicais ressaltadas nos papéis das princesas da floresta e da fada que, trazendo consigo sua varinha de condão, derrubam fortes feiticeiras, os nobres e os caçadores maus, afastando ainda a magia negra, bem como, mediante as suas interven-

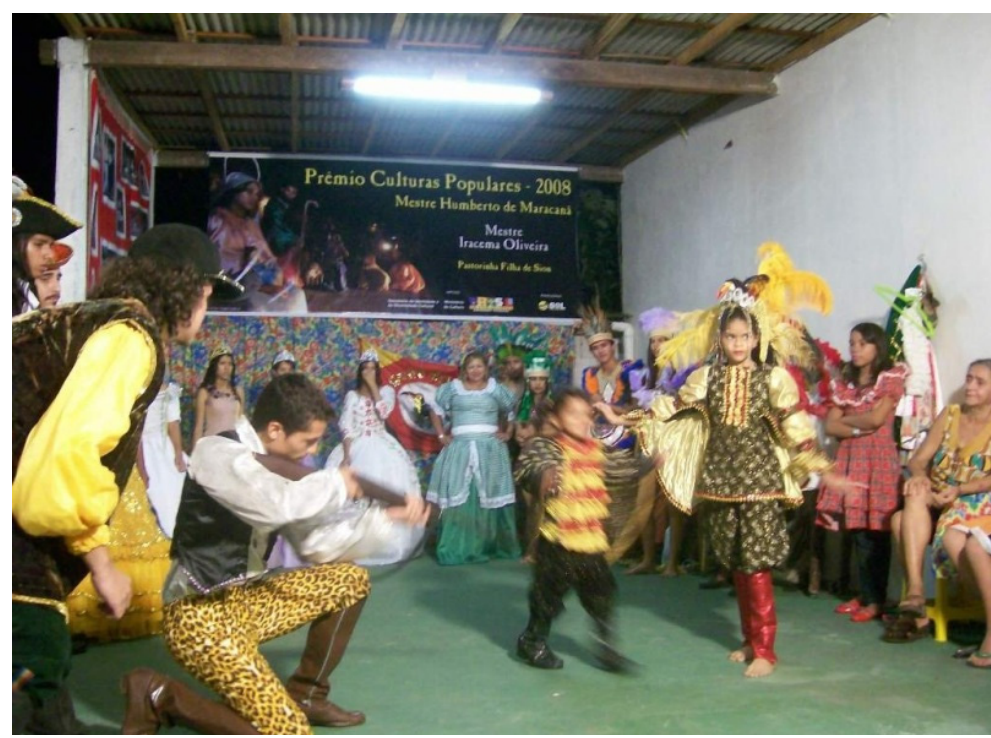

Figura 5 - Fotografia da caçada do Pássaro Tucano, 2009. Autoria: Eliane Suelen Silva. Acervo de pesquisa.

ções mágico-miraculosas, acabam por curar a ave abatida ou a ressuscitá-la da morte, tal qual fênix renovada ${ }^{17}$.

Conforme a guardiã do Tucano, a fada deve ser representada por uma bela jovem, de rosto bonito, andar suave, estando, portanto, relacionada ao bem, ao dia, à luz e à justiça, seja da natureza, seja dos homens. Enquanto à princesa da floresta cabe proteger a natureza dos infortúnios que poderiam degradá-la; à fada cabe intermediar os conflitos entre os mortais; apontar o caminho correto àqueles que vacilam; orientar os angustiados diante de suas tormentas; alertar sobre os perigos aos incautos e, em última instância, restaurar por si mesma a paz no mundo.

A fada e a princesa da floresta evocam a imagem da redenção. Seu universo "é o da estabilidade, o da realização, parece estar sempre em estado de frescor, de limpidez, de vigor, em oposição ao mundo das feiticeiras, feito de podridão e trevas, decomposição e transformação, insaciabilidade e incompletude" (Moura1997: 187). Feiticeiras e fadas ocupam posições diametralmente antagônicas e irreconciliáveis no universo narrativo dos Pássaros Juninos. 
Quem são as feiticeiras? Elas revelamse criaturas da sombra, mulheres marginais, ambíguas, poderosas, pois conhecedoras da magia. Seus poderes enfeitiçam os homens, transgredindo a ordem e a lógica ordinária, como aponta Caillois (1938). Todavia, como nos diz Moura, longe de serem monolíticas tal quais as fadas, as feiticeiras são humanizadas. Não raro, suas ações perversas e vingativas originam-se de amores mal sucedidos, terríveis traumas e recordações. Se a feiticeira pode ser "romântica", que age por impulsos passionais, por outro lado, pode personificar toda a ambição, a inveja e a cobiça, evocando a imagem de uma maldade naturalizada. Enquanto mulher, a feiticeira carrega o perigo e a impureza, tal qual por vezes são apresentadas as mulheres nobres nas narrativas dos Pás-

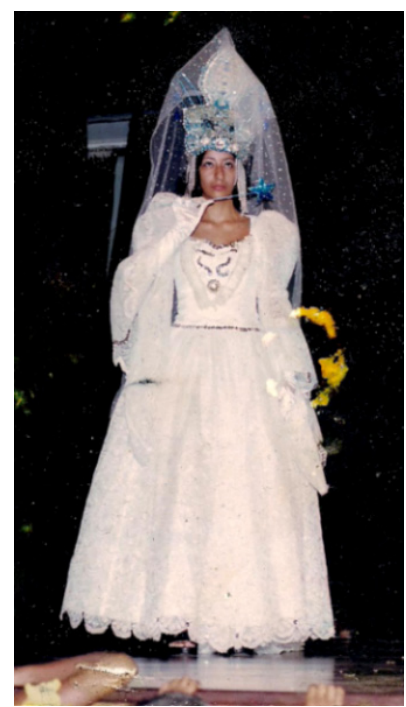

Figura 6 - Fotografia de fada do Pássaro Rouxinol. Autoria desconhecida. Acervo pessoal de Wanderley Rodrigues. saros. $\mathrm{O}$ estado da mulher é liminar ${ }^{18}$. Nas cenas de feitiçaria, outros personagens surgem em contraste com o sério e profundo momento de concentração para realização dos feitiços. São os matutos, facilmente identificáveis pelas posturas que apresentam, pois a "arte performática" (Londres 2004) dos brincantes revela as técnicas corporais e vocais presentes no contexto amazônico. Portam-se curvados, andar desajeitado, voz carregada de sotaque nortista ou nordestino. A matutagem representa com toda eloquência o caráter mestiço do povo amazônida, apresentando o caboclo do Pará e o cearense imigrante, com valores e imaginários igualmente mestiços: ora crêem no deus cristão, chamando-o nos momentos de medo, ora tomam

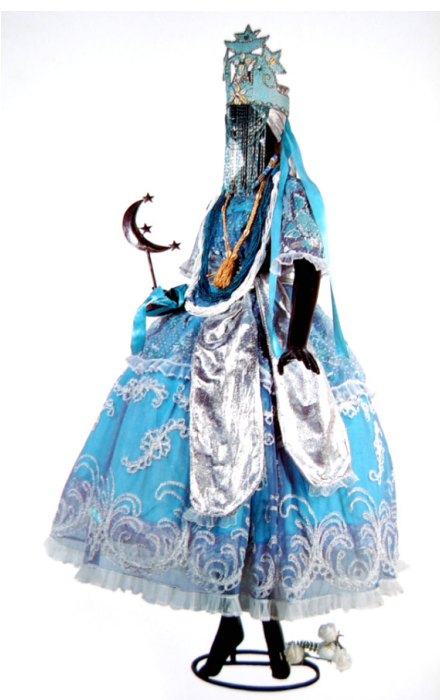

Figura 7 - Iconografia de Orixá Iemanjá. Reproduzida da obra de Castro (1989). 


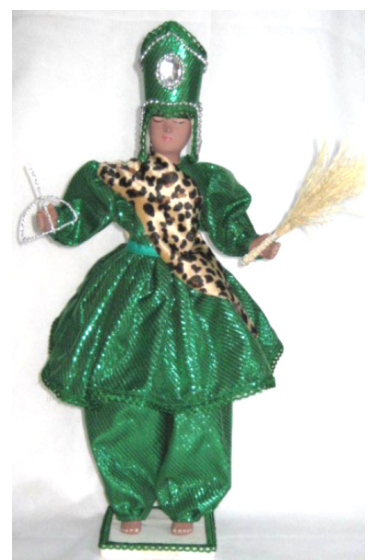

Figura 8 - Iconografia de Orixá Oxossi. Disponível em <http://www.tropicalbr. com.br/portugues/orixas/orixa11.jpg>. Acesso em: 28 jul 2009.

parte e ajudam nos trabalhos da feiticeira. À matutagem é permitido extravasar as emoções e valores, sejam eles contraditórios, ridículos, ou mesmo, jocosos. Aos matutos, por certo, cabe intercalar cenas em que o drama é suavizado pela irrisão e a eloquência de seus personagens. O Pássaro Junino está, desta forma, permeado

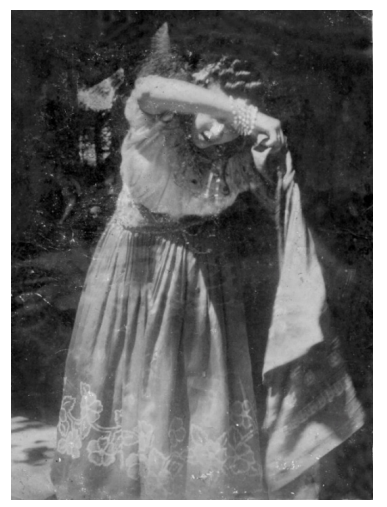

Figura 10 - Fotografia de feiticeira do Pássaro Rouxinol. Autoria e data desconhecidas. Acervo pessoal de Wanderley Rodrigues.

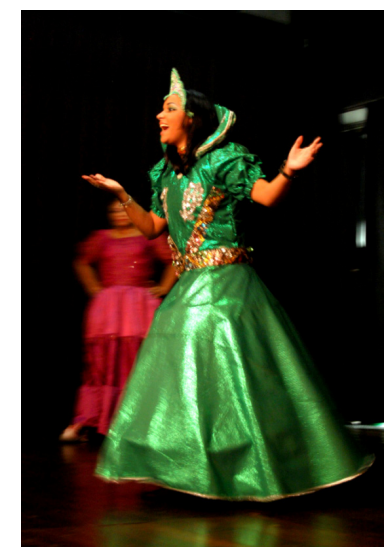

Figura 9 - Fotografia de princesa da floresta do Pássaro Tucano, 2009. Autoria: Helio Netto. Acervo de pesquisa.

por esses momentos que vigoram entre o melodrama (drama) e o jocoso, os quais "funcionam como esvaziamento de tensões" (Loureiro 2001).

Posicionados de forma oposta à jocosidade e ao lado "plebeu" da brincadeira, portanto, aparecendo como contraponto ao satírico do espetáculo, é possível encontrar os nobres que

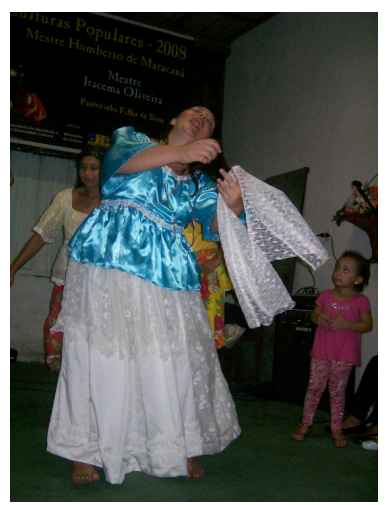

Figura 11 - Fotografia de feiticeira do Pássaro Tucano, 2009. Autoria: Eliane Suelen Silva. Acervo de pesquisa. 
conduzem à cena de maneira pomposa e altiva, indicando de alguma forma o caráter sério do jogo. Os nobres se encarregam da parte em que desembocam os dramas familiares e amorosos, carregados de teor melodramático.

Sendo assim, enquanto experiência lúdica que evoca um conjunto de imagens simbólicas, vivida na brincadeira-ritual que é o Pássaro Junino, torna-se imprescindível à dinâmica jogo-sério (Huizinga 1996), como expressão da criatividade humana. Segundo Refkalefsky (2001: 156), a indumentária utilizada pelos personagens dos Pássaros transmite esta oposição entre as classes sociais ali representadas e, no caso dos personagens da nobreza, "os materiais que são empregados na confecção das roupas, procuram demonstrar riqueza, usando materiais ditos caros e refinados, como a seda, renda e outros". A mesma autora ressalta que o figurino utilizado nos Pássaros é uma forma de tornar real aquilo que é sonho, portanto a indumentária se configura como uma forma simbólica de ascensão social desses brincantes, que em sua maioria são de origens "populares". Em outro ponto estão os índios, organizados socialmente em torno de uma maloca liderada pelo chefe a quem devem obediência, que não raro se aliam às vítimas e aos personagens desafortunados da trama, curando seus ferimentos, através da figura do pajé, ou oferecendo-lhes abrigo seguro, acionando a imagem do bom selvagem. Normalmente, os índios são apresentados como protetores da floresta e, por conseguinte, do próprio pássaro, sempre alvo de cobiça. Em outras vezes, a "maloca" figura como mera atração,

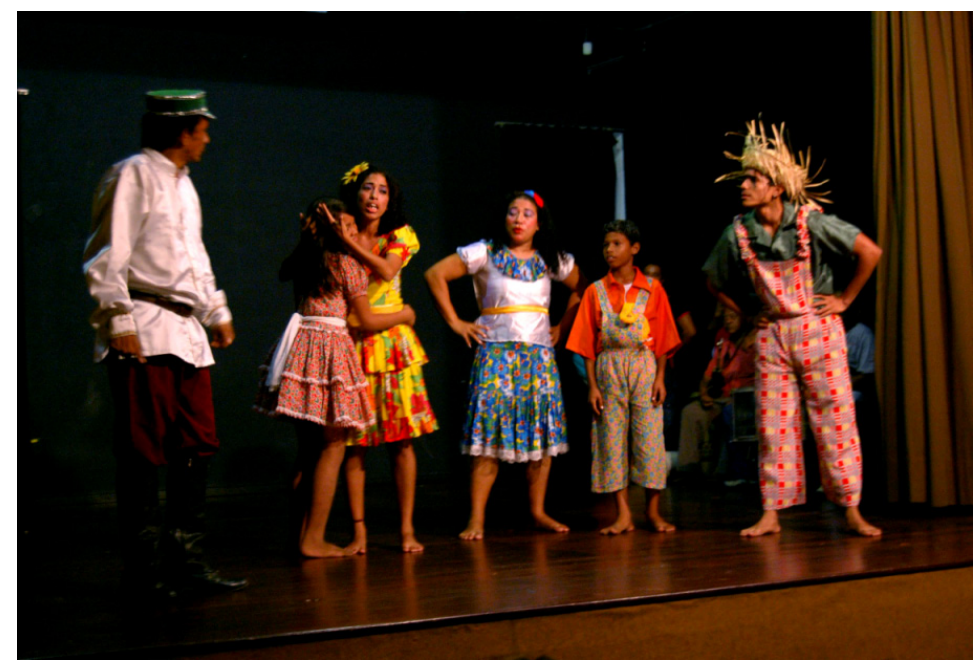

Figura 12 - Fotografia de matutos do Pássaro Tucano, 2009. Autoria: Helio Netto. Arquivo de pesquisa. 


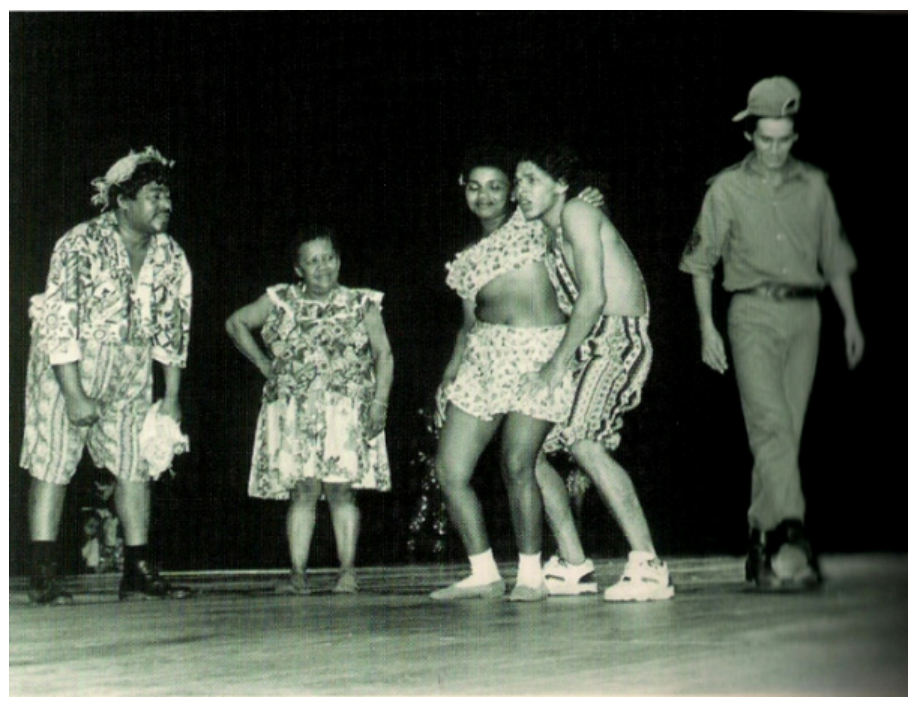

Figura 13 - Fotografia de matutos do Pássaro Beija-Flor, 1996. Autoria desconhecida. Reproduzida da obra de Moura (1997).

desenvolvendo danças ritualizadas e diálogos em "língua indígena", estranha a todo o restante dos personagens. Somente a denominada "índia favorita" ou "branca" - um "paradoxo criativo" da miscigenação - é capaz de promover o diálogo entre seus parentes indígenas e os outros personagens da trama. Em todo caso, os índios aparecem de maneira estereotipada, com extravagantes e alegóricas indumentárias, repletas de plumagens, de adornos e de acessórios, que remetem a uma estética que fica entre o camavalesco e as referências aos grupos nativos norteamericanos - evocando imagens de filmes hollywoodianos, que, de acordo com Moura, também serviu como referência na época em que as artes cinematográficas estrangei- ras tiveram seu primeiro momento de ascensão no estado paraense. A fim de entendermos melhor as formas ético-estéticas relacionadas aos modos como se constrói a trama ou a intriga da narrativa dos Pássaros Juninos, passemos agora a levantar alguns questionamentos concernentes a característica de personagens recorrentes neste gênero teatral. Como já foi dito essa predominância do mestiço e da bricolagem são características que permeiam todas as indumentárias e as narrativas dessas manifestações, sendo que alguns autores apontam para a marcada influência indígena e negra, revelando uma maneira de "resistência" dos grupos étnicos, e de suas expressões culturais, perpetuarem-se frente à expansão hegemônica da cultura europeia.

Acreditamos, no entanto, que de for- 


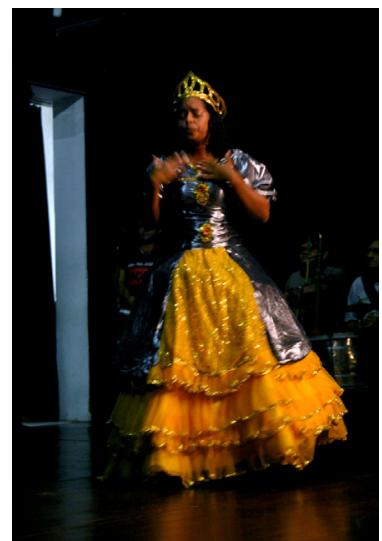

Figura 14 - Fotografia de nobre do Pássaro Tucano, 2009. Autoria - Helio Netto. Arquivo de pesquisa.

ma alguma há como precisar em que momento tais influências se consolidaram, nem que o motivo para tanto seja tão somente o da "resistência". Se revisitarmos a discussão clássica do que se denominou "cultura popular", perceberemos que é típico deste tipo de análise entendê-la sempre em oposição a uma cultura dita erudita, ou dominante. Pensar em uma forma de "resistência" a cultura europeia é negar completamente a constituição dessa miscelânea cultural que é própria da experiência amazônica. A presença europeia é tão forte na constituição dessas manifestações, que pensá-las como uma forma de resistir a ela é cair completamente no "pessimismo sentimental" 19 .

Se há algum tipo de "resistência" é aquela de caráter plástico que "antropofagiza" simbolicamente a cultura do Outro, inserindo no universo brincante dos Pássaros Juninos alguns de

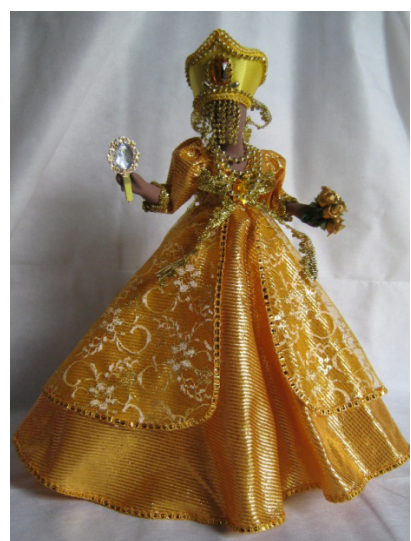

Figura 15 - Iconografia de Orixá Oxum. Disponível em <http://www.tropicalbr. com.br/portugues/fotosgrandes/orixa02. jpg>. Acesso em: 28 jul 2009.

seus elementos, permitindo que os conteúdos simbólicos de "oprimidos" e de "opressores" (para usar jargões carregados de conteúdo ideológico) se misturem, confundindo significados e engendrando outros no cenário da sociabilidade de caráter festivo. $\mathrm{O}$ "terceiro incluído" instaura outra ordem das coisas nos jogos de poder, ritualizados e performatizados nas maneiras de viver dos coletivos no contexto belenense. Portanto, não se trata de operar com oposições binárias excludente (tipo ou...ou), mas sim de refletir sobre as diferenças coligadas que apontam para o "e...e" presentes em sistemas culturais dinâmicos, representados pelo "gosto" que une e recicla experiências diversas, eis a força imaginária do popular na Amazônia digerindo o erudito. Sendo assim, falar em ideologia significa referi-la a uma dimensão da vida social relativa a um sistema de ideias (Dumont 1985) detentor de hierarquias (e jogos de poder), por certo, mas em 


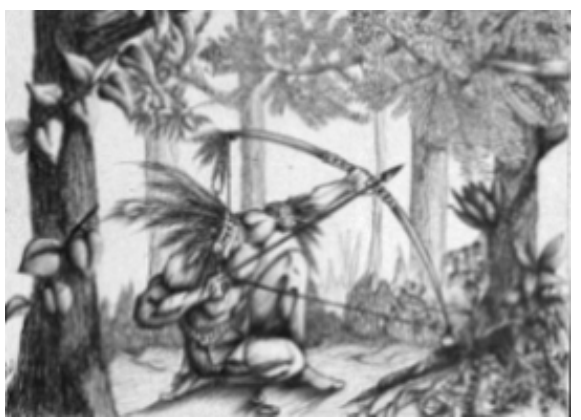

Figura 16 - Iconografia de Caboclo da Umbanda. Autoria desconhecida. Disponível em: <http://www.artefolk.com.br/wpcontent/uploads/2008/03/_caboclos. jpg >. Acesso em: 29 out 2009.

franca negociação e fluxo criativo. Criticamente, o que queremos levantar aqui é que, partindo deste caráter de mestiçagem, percebemos que a manifestação junina em questão é resultado de apropriações e releituras de elementos que circulam no imaginário e no cotidiano paraense. Estamos assim de acordo com Chartier, ao entender que o popular "qualifica [...] um modo de utilizar objetos ou normas que circulam na sociedade, mas que são recebidos, compreendidos e manipulados de diversas maneiras" (Chartier 1995: 6).

Com intuito de exemplificar essas questões, é interessante evocarmos brevemente os Terreiros de Mina, religião de matriz africana onde os seus caboclos se apresentam como civilizados de origem nobre, como Antonio Luís (Corre-Beirada), Filho de Dom Luís, rei de França e o rei São Sebastião. O "Dão" Sebastião, como é conhecido, pode ser considerado como uma das entidades de maior prestígio, figura lendária, justamente por ter sido

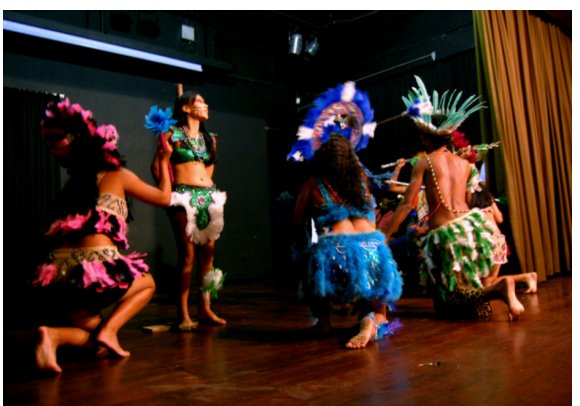

Figura 17 - Fotografia de índios do Pássaro Tucano, 2009. Autoria - Helio Netto. Arquivo de pesquisa.

um personagem histórico, já que foi o décimo sexto rei de Portugal, que segundo a lenda se encantou na Ilha dos Lençóis (Pereira 2008). Sem mais delongas $^{20}$, o nosso intuito aqui é apontar como a influência europeia é incorporada ao imaginário amazônico repleto de referências indígenas, de tal forma, que em oposição a uma resistência, há na verdade a constituição de uma das principais características da identidade local, a mestiçagem de conteúdos simbólicos heteróclitos cujas imagens emulam em algumas manifestações lúdicas e religiosas $^{21}$.

Considerando que tais apropriações são marcadamente fortes nos Pássaros Juninos, certas semelhanças e convergências de imagens nos levam a influir como algumas características manifestadamente de origem africana, por exemplo, se fazem presentes. A indumentária e a função da princesa da floresta apresentam similitudes com a vestimenta de Oxossi, um orixá masculino de origem africana e característi- 
cas noturnas que, segundo a mitologia, é um espírito da floresta e dos bosques, tendo por função presidir a caça e proteger os caçadores. $\mathrm{Na}$ mitologia, Oxossi foi responsável por flechar um grande pássaro que havia sido mandado por feiticeiras à sua aldeia no dia de uma grande celebração real. Para tal feito vários caçadores haviam tentado abater o pássaro e, mesmo dispondo de várias flechas, todos falharam. Oxossi, dispondo de uma única flecha, mas amparado por sua mãe e os conselhos de um babalấ, foi o responsável por abater a ave e restaurar a paz em sua aldeia (Castro 1989).

$\mathrm{Na}$ peça intitulada "A Vingança da Feiticeira" é a princesa da floresta quem salva o caçador e a "índia branca" das mãos dos índios que, sendo contrários ao relacionamento dos dois, os fizeram reféns, indicando um maniqueísmo que opõe índios a não-índios. Vale lembrar que a princesa da floresta, junto com a fada, são nesta peça os seres encantados responsáveis por quebrar o sortilégio de feiticeiras e livrar as florestas das pessoas de "má coração", restaurando a paz do reino sob sua proteção. Poderíamos ser levados a crer que o fato de uma princesa da floresta salvar o caçador seja uma discrepância, no entanto, na peça mencionada, o caçador não representa características maléficas, e sim deseja capturar a ave por considerá-la bela, pois anseia por sua formosura e pela felicidade que pode proporcionar. Assim, esta narrativa do Pássaro converge com a de Oxossi no que diz respeito à indumentária e também quanto à proteção da floresta e dos homens considerados bons, muito embora devamos salientar que, neste último caso, o feitiço que se quer abater é coincidentemente manifesto por um pássaro, enquanto na manifestação que analisamos o pássaro carrega virtudes benéficas.

É percebendo tais nuances que inferimos que manifestadamente mais do que um simples "hibridismo", os Pássaros Juninos carregam consigo um dos traços mais marcantes das expressões culturais amazônicas, ponto crucial de delimitação de aspectos da identidade, uma vez que o fantasioso e o mítico tão presente no universo amazônico se manifesta nas plumas, nos brilhos e nos gestos desses personagens que, representando o fantástico, performatizam o realismo do cotidiano. Não se trata, portanto, de meros rebeldes resistentes à dominação, mas, sim, de fundadores de uma unicidade repleta de potência de agregação de símbolos e de produção imagética, onde o gênio criativo instaura formas sensíveis de hermenêuticas e de significação do mundo.

\section{NOTAS}

${ }^{1}$ Como demonstra Lima (2008: 23), baixadas são "espaços sócio-urbanisticamente periféricos, de convivência majoritária das camadas populares da Zona Metropolitana de Belém". Entendemo-las da mesma forma, salientando ainda seu caráter extremamente heterogêneo, resultado de um processo de desenvolvimento social desigual, que, pensando através de imagens, pode encontrar-se refletido em uma rua do mesmo bairro periférico, através de 
construções residenciais que, lado a lado, destoam entre si: umas de madeira, outras, alvenarias com seus carros na garagem; ressaltando a heterogeneidade de recursos e formas de vida que podem ocupar um espaço contiguo.

${ }^{2}$ Para uma definição geral, por brincante estamos tomando o participante de folguedos ou brincadeiras populares espontâneas. Difere, portanto, da noção de ator enquanto participante do teatro "profissional" ou "acadêmico".

${ }^{3}$ Partimos das reflexões de Clifford (1998: 65-66) acerca da alegoria a fim de pensarmos o seu "caráter narrativo" no que se refere ao Pássaro Junino, uma vez que "normalmente denota uma prática na qual uma ficção narrativa continuamente se refere a outro padrão de idéias ou eventos".

${ }^{4}$ Em Belém do Pará, por Belle Époque compreende-se o período relativo ao auge da produção e comércio da borracha, que movimentou a economia e a urbanização da cidade, entre 1870 e 1920. Para o contexto paraense ver Sarges (2002) e para o amazonense ver Daou (2000).

${ }^{5}$ Em relação ao lúdico e ao jogo nos apoiamos nas reflexões de Johan Huizinga (1996).

${ }^{6}$ Os cordões de bichos são manifestações teatrais onde existe um animal que é considerado o patrono do folguedo, sendo que o desenrolar da peça remete a esta figura. Os bichos escolhidos variam de grupo a grupo, podendo estar representado por uma ave, um mamífero ou mesmo, um peixe, para tanto ver Figueiredo \& Tavares (2006). Em Belém, a escolha de pássaros como patrono de tais folguedos foi predominante.

${ }^{7}$ Pastorinhas, conforme Figueiredo \& Tavares (2006:155), seriam o "Auto de Natal representando o nascimento de Jesus".

${ }^{8}$ Para exemplos destas narrativas, consultar a série Cadernos do Instituto de Artes do Pará (IAP) que publicou algumas peças completas de Pássaros Juninos, entre estas a de Oliveira (2001), encenada pelo Pássaro Junino Tucano, e Souza (2001), encenada pelo Pássaro Tem-Tem.

9 Sobre as relações entre as "artes performáticas" e o patrimônio imaterial ver os vários artigos presentes na coletânea organizada por Teixeira et al. (2004).

${ }^{10} \mathrm{O}$ mestiço é aqui utilizado em sua concepção de mistura ou gradação entre elementos distintos, esvaziado de conotações pré-concebidas. Para leituras aprofundadas, consultar Bakhtin (1996) e Gruzinski (2001).

${ }^{11}$ Guardiã é a pessoa responsável por cuidar, administrar, agendar apresentações, enfim, tomar decisões a respeito de todos os assuntos e demandas que se relacionem ao grupo. Prefere não se intitular "proprietária" do Tucano, mas espécie de orientadora, conforme aparece no seguinte trecho: "Prefiro dizer que sou guardiã, porque não sou dona mesmo, né?" (Iracema de Oliveira, citada por Moura 1997: 116)

12 Para melhores elucidações consultar Todorov (1989).

${ }^{13} \mathrm{Nas}$ fotografias de autoria de Helio Netto o uso de flash foi evitado, buscando enfatizar a luz que compunha o espetáculo na tentativa de compartilhar com o leitor das imagens um pouco da iluminação que ajuda a compor o cenário, onde os personagens performatizam. No entanto, devido à baixa iluminação fez-se necessário aumentar a sensibilidade do sensor digital (ISO) e diminuir a velocidade da obturação, fazendo com que algumas fotos apresentemse riscadas, desfocadas ou escuras demais. Entretanto essa "baixa velocidade" atri- 
buiu certo "movimento" a algumas fotografias, suscitando melhor as gestualidades e dinamicidade dos performers.

${ }^{14}$ Para maiores elucidações consultar a discussão sobre porta-pássaro realizada por Maués (2009).

${ }^{15}$ Sobre as complexas interações entre animus e anima consultar Durand (1989).

${ }^{16}$ Marton Maués (2009: 134-135), afirma o seguinte acerca do pássaro (e da portapássaro): "Mesmo que sua estória deixe de ser o centro, como no caso do pássaro melodrama, é ela o mote para que as demais estórias sejam contadas. E é sua saga - caçada, morte e ressurreição - que todos conhecemos antes mesmo de abrir-se o pano, pois ela é o componente estrutural de todo o espetáculo [...]. Ele [o pássaro] é o objeto de desejo de quase todos os personagens e também dos espectadores. É este desejo que provoca sua morte, mas também a sua ressurreição. 'Ele incorpora os simbolismos da morte e ressurreição, de liberdade e prisão, de magia, de surrealidade e do espetacular. O percurso dos personagens na peça pode se alterar. Mas o destino do pássaro é sempre o mesmo: ele é caçado, perseguido, morto e, por interferência mágica de algum personagem, ele ressuscita' (Refkalefsky 2001: 151). Loureiro vê na figura do porta-pássaro 'a imagem mítica do homem-pássaro - o pássaro na cabeça do homem ou da mulher no Egito antigo, onde essa figura simbolizava a alma de um morto partindo, ou a visita de um deus à terra'. E pergunta-se se não estaria aí, neste símbolo que é o porta-pássaro, representada 'a alma nativa que não morre, que não pode ser morta? [...] Uma espécie de fênix tropical da alma de uma cultura?' (Loureiro 2001: 321)'.’”

${ }^{17}$ As reflexões de Charone (2009: 143), apontam para o fato de que "[p]ara proteger o pássaro, entram em cena outros personagens, com poderes mágicos, como a fada, a maloca (índios), e a cena da macumba, para impedir a perseguição do caçador. O balé e os matutos entram com outros temas, para aliviar as tensões do melodrama".

18 Tal imagem reverbera na figura assustadora da Matintaperera - ser míticofantástico que assombra os viventes, encarnado em uma mulher que experiencia a zoometamorfose em pássaro (metáfora para a mulher-pássaro). Para tanto ver Motta-Maués e Villacorta (2008), Fares (2008). Evoca ainda na imagem liminar da mulher que não deve tocar os objetos de caça ou pesca dos homens, evitando que fiquem panema, ou seja, que sobre os homens recaia uma má sorte - uma "malineza" - que os prejudique nas suas tarefas de obtenção de alimento junto aos naturais, ficando assim, "empanemados". Para tanto ver Maués e Motta-Maués (1978) e Galvão (1979).

${ }^{19}$ Consultar Sahlins (1997).

${ }^{20}$ Aqui tratamos de maneira superficial um elemento do Tambor de Mina, já que nosso intuito é somente estabelecer algumas relações entre este e os Pássaros Juninos. Para um maior aprofundamento consultar o trabalho de Ferreti (1992) e Vergolino (1976).

21 Sobre "performance afro-ameríndia" consultar o artigo de Ligiéro (2004).

\section{REFERÊNCIAS}

Bachelard, G. 1988. A poética do devaneio. São Paulo: Martins Fontes.

Bakhtin, M. 1996. A cultura popular na Idade Média e no Renascimento. São Paulo: Hucitec; Brasília: EdUNB.

Caboclo na Umbanda. Altura: 404 pixels. Largura: 500 pixels. 100 dpi. 24 BITS 
263 KB. Formato JPG. Compactado. Disponível em: <http://www.artefolk.com. br/wp-content/uploads/2008/03/ caboclos.jpg >. Acesso em: 29 out 2009.

Caillois, R. 1938. Le mythe et l'homme. Paris: Gallimard.

Cancela, C. D. 2009. Paisagens e trajetórias na Belém da economia da borracha, in Paisagem e cultura: dinâmicas do patrimônio e da memória na atualidade. Organizado por C. D. Cancela \& F. L. A. da Silveira, pp. 217-228. Belém: EDUFPA.

Castro, H. F. M. 1989. Os orixás no Brasil. Spala Editora Limitada: Rio de Janeiro.

Certeau, M. de. 1994. A invenção do cotidiano: artes de fazer. Rio de Janeiro: Vozes.

Charone, O. 2009. O teatro dos pássaros como uma forma de espetáculo pós-moderno. Revista Ensaio Geral 1:139-146.

Chartier, R. 1995. “Cultura popular": revisitando um conceito historiográfico. $R e$ vista Estudos Históricos 16:179-192.

Clifford, J. 1998. A experiência etnográfica: antropologia e literatura no século XX. Rio de Janeiro: UFRJ.

Daou, A. M. 2000. A belle époque amazônica. Rio de Janeiro: Jorge Zahar.

Dumont, L. 1985. O individualismo: uma perspectiva antropológica da ideologia moderna. Rio de Janeiro: Rocco.

Durand, G. 1989. As estruturas antropológicas do imaginário. Lisboa: Presença. tora UNB. 1995. A fé do sapateiro. Brasília: Edi-

Fares, J. A. 2008. A matintaperera no imaginário amazônico, in Pajelanças e religiōes africanas na Amazônia. Organizado por R. H. Maués \& G. M. Villacorta, pp. 311-326. Belém: EDUFPA.

Ferreti, M. 1992. Repensando o turco no tambor de mina. Estudos Afro-Asiáticos 15:56-70. Disponível em: <http://www. afroasia.ufba.br/pdf/afroasia_n 15_p56. pdf $>$. Acesso em: 30 jun 2009.

Figueiredo, S. L. \& A. P. Tavares. 2006. Mestres da cultura. Belém: EDUFPA.

Foucault, M. 2007. História da sexualidade I. Rio de Janeiro: Graal.

Gadamer, H. G. 2002. Verdade e Método I: tracos fundamentais de uma hermenêutica filosófica. Rio de Janeiro: Vozes.

Galvão, E. 1979. Encontro de sociedades: indios e brancos no Brasil. Rio de Janeiro: Paz e Terra.

Gruzinski, S. 1991. La colonización de lo imaginario. México: Fondo de Cultura Económico.

1992. A guerra das imagens e a ocidentalização da América, in América em tempo de conquista. Organizado por R. Vainfas, pp. 198-207. Rio de Janeiro: Jorge Zahar.

2001. O pensamento mestiço. São Paulo: Companhia das Letras.

Huizinga, J. 1996. Homo ludens. São Paulo: Perspectiva.

Huppes, I. 2000. Melodrama: o gênero e sua permanência. São Paulo: Ateliê Editorial.

Lévi-Strauss, C. 1976. O pensamento selvagem. São Paulo: Nacional.

Ligiéro, Z. 2004. A performance afroameríndia: tradição e transformação, in Patrimônio imaterial, performance cultural e (re) tradicionalização. Organizado por J. G. L. Teixeira et al. pp. 88-93. Brasília: ICS-UnB.

Lima, A. 2008. "É a festa das aparelhagens!": performances culturais e discursos sociais. Dissertação de mestrado, Programa de Pós-Graduação em Ciências Sociais (Antropologia). Universidade Federal do Pará, Brasil. 
Londres, C. 2004. Patrimônio e performance: uma relação interessante, in Patrimônio imaterial, performance cultural e (re)tradicionalização. Organizado por J. G. L. Teixeira et al. pp. 19-30. Brasília: ICS-UnB.

Loureiro, J. J. P. 1995. Cultura amazônica: uma poética do imaginário. Rio de Janeiro: Cejup.

Maffesoli, M. 1987. O tempo das tribos: o declínio do individualismo nas sociedades de massa. Rio de Janeiro: Forense-Universitária. 1994. O poder dos espaços de representação. Revista Tempo Brasileiro 116:59-70. - 1996. No fundo das aparências. Petrópolis: Vozes.

Manguel, A. 2001. Lendo imagens: uma bistória de amor édio. São Paulo: Companhia das Letras.

Maués, M. 2009. Breve vôo sobre o universo imagético do pássaro junino paraense. Revista Ensaio Geral 1:133-138.

Maués, R. H. \& M. A. Motta-Maués. 1978. O modelo da "reima": representações alimentares em uma comunidade amazônica. Anuário Antropológico 77:120-147.

Menezes, B. 1972. Boi-bumbá - Auto popular: festejos e folguedos juninos no Pará. Belém: Imprensa oficial.

Montoya, A. R. de. [1639] 1997. Conquista Espiritual. Porto Alegre: Martins Livreiro.

Motta-Maués, M. A. \& G. M. Villacorta. 2008. Matintapereras e pajés: gênero, corpo e cura na pajelança amazônica, in Pajelanças e religiões africanas na Amazônia. Organizado por R. H. Maués \& G. M. Villacorta, pp. 327-348. Belém: EDUFPA.

Moura, C. E. M. 1997. O teatro que o povo cria. Pará: Secult.

Oliveira, F. 2001. A justiça das selvas. Belém: IAP.
Orixá Oxossi. Altura: 401 pixels. Largura: 629 pixels. 300 dpi. 24 BITS. 60,3 KB. Formato JPG. Disponível em: <http://www. tropicalbr.com.br/portugues/orixas/ orixa11.jpg >. Acesso em: 28 jul 2009.

Orixá Oxum. Altura: 576 pixels. Largura: 768 pixels. 180 dpi. 24 BITS. 181 KB. Formato JPG. Disponível em: <http:// www.tropicalbr.com.br/portugues/fotosgrandes/orixa02.jpg >. Acesso em: 28 jul 2009.

Pereira, M. de J. F. 2008. A encantarias dos "filhos do rei Sebastião" na ilha dos Lençóis, in Pajelanças e religiões africanas na Amazônia. Organizado por R. H. Maués \& G. M. Villacorta, pp. 149-179. Belém: EDUFPA.

Piault, M. H. 2001. Real e ficção: onde está o problema?, in Imagem e memória: ensaios em antropologia visual. Organizado por M. Khouri, pp. 151-171. Rio de Janeiro: Garamond.

Refkalefsky, M. 2001. Pássaros... bordando Sonbo: funcão dramática do figurino no Teatro dos Pássaros em Belém do Pará. Belém: IAP.

Ribeiro, J. da S. 2004. Antropologia visual: da minúcia ao olhar distanciado. Porto: Edições Afrontamento.

Ricoeur, P. 1994. Tempo e narrativa. São Paulo: Papirus.

Sahlins, M. 1997. O "pessimismo sentimental" e a experiência etnográfica: por que a cultura não é um "objeto" em via de extinção (parte I). Mana 3:41-73.

Salles, V. 1994. Épocas do teatro no Grão-Pará ou Apresentação do teatro de época. Belém: UFPA.

Sansot, P. 1979. Les formes sensibles de la vie sociale. Paris: PUF.

Sarges, M. N. 2002. Belém: riquezas produzindo a Belle-Époque (1870-1912). Belém: Paka- 
Silva, E. S. O. et al.

Tatu.

Simmel, G. 1983. Sociologia. Organização de Evaristo de Moraes Filho. São Paulo: Ática.

Souza, L. P. 2001. Amorproibido ou Sangue do meu sangue. Belém: IAP.

Teixeira, J. G. L. et al. 2004. Patrimônio imaterial, performance cultural e (re)tradicionalização. Brasília: ICS-UnB.

Vergolino-Silva, A. 1976. O Tambor das flores: uma análise da Federação Espírita Umbandista e dos Cultos Afro-Brasileiros do Pará (1965-1975). Dissertação de mestrado, Programa de Pós-Graduação em Antropologia Social. Universidade Estadual de Campinas, Brasil.

Recebido em 04/04/2010.

Aprovado em 14/06/2010. 